\title{
Sowing Date influences cotton leaf curl disease (CLCuD) incidence and productivity of non-Bt cotton cultivars
}

Khuram Mubeen ${ }^{*}$, Muhammad Naveed Afzal $^{2}$, Muhammad Tariq ${ }^{2}$, Muhammad Ahmad ${ }^{2}$, Dilbaugh Muhammad ${ }^{2}$, Muhammad Shehzad ${ }^{3}$, Mudassir Aziz ${ }^{1}$ and Muhammad Waqas Yonas ${ }^{1}$

1. Department of Agronomy MNS University of Agriculture Multan, Pakistan

2. Agronomy Section, Central Cotton Research Institute Multan, Pakistan

3. Department of Agronomy, The University of Poonch Rawalakot (AJK) 12350, Pakistan

*Corresponding author's email: khurram.mubeen@mnsuam.edu.pk

Citation

Khuram Mubeen, Muhammad Naveed Afzal, Muhammad Tariq, Muhammad Ahmad, Dilbaugh Muhammad, Muhammad Shehzad, Mudassir Aziz and Muhammad Waqas Yonas. Sowing Date influences cotton leaf curl disease (CLCuD) incidence and productivity of non-Bt cotton cultivars. Pure and Applied Biology. Vol. 11, Issue 1, pp26-34. http://dx.doi.org/10.19045/bspab.2022.110003

Received: 13/01/2021 Revised: 26/03/2021

Accepted: 07/04/2021

Online First: 17/04/2021

\section{Abstract}

Disease infestation in crop plants can be reduced by choosing the most suitable sowing date for different cultivars of the same crop. A two-year study was conducted to know the best sowing date for cotton on silt loam soil in a sub-tropical arid climate. Two cotton cultivars i.e. CIM-612 and CIM-573 were sown for two consecutive years. Moreover, CIM-591 was grown in year 1 and Cyto-124 in year 2, at five different dates (April 15, May 01, May 15, June 01 and June 15). By delaying the sowing, plant height, number of bolls per plant and seed cotton yield $\left(\mathrm{kg} \mathrm{ha}^{-1}\right)$ was decreased while cotton leaf curl disease (CLCuD) incidence (\%) was increased gradually. All the varieties in general sown earlier showed higher yield and reduced incidence of CLCuD. However, among non- $B t$ cultivars, performance of CIM-612 was overall better when sown on April 15 during both the years with minimum CLCuD incidence and improved seed cotton productivity. Hence non-Bt cotton cultivar CIM-612 may be sown on April 15 in cotton core zone of Punjab (Pakistan).

Keywords: CLCuD; Gossypium hirsutum; Seed cotton yield; Sowing date

\section{Introduction}

Cotton is an important cash crop of Pakistan and is a significant source of foreign exchange earnings. It is also a major oilseed crop of the country [1]. In Pakistan, cotton is grown both for its fiber and extraction of the edible oil from seed cotton. Cotton is grown on 2,699 thousand hectares in Pakistan, with total production of 11.935 million bales and average yield of $752 \mathrm{~kg} \mathrm{ha}^{-1}$ [2].
Cotton crop now a day is facing some serious threats which altogether have forced the scientists to standardize the production practices and enhance the fiber qualities to meet the international standards at the same time. Changing climate is acting like a precursor for these threats. Abiotic stresses (drought, temperature, salts and water stresses) determine the fate of the cotton crop [3]. Seed rate, spacing, plant protection, nutrient and water management beside 
varieties and sowing date are of pivotal significance in this context. Among agronomic factors, sowing date is very important to harvest a profitable final yield $[4,5]$. Change in sowing time states change in all the weather elements at the time of sowing. A crop requires specific degree days and heat units along with other weather units throughout the life cycle in a certain proportion for moving from one growth step to the other. An early weather changes in temperature, humidity etc; lower or higher will be incorporated into plant biological system which will last until the end in subsequent growth and developmental stages. Plants normal growth and development will be badly hampered consequently. The early sowing of cotton will make the plant to face different set of conditions in the field while late sowing will provide for a totally different set of growing conditions having different implications on yield, fiber characters and virus abundance.

Farmers sow cotton in March and even in February to avoid the cotton leaf curl disease $(\mathrm{CLCuD})$ problem, instead of May-June [6]. Early sowing may aid in reducing the incidence of CLCuD by providing early favorable environment to the crop stand. Early planting of cotton enhances yield components and seed cotton yield, increased growth, reduced flower and boll shedding over late sown crop [4, 6, 7]. Early stand establishment will make crop more vigorous and less prone to damage by virus which ultimately will aid in better outcomes in terms of production. Furthermore, late planting deteriorates quality of seed cotton [8-10]. But these varying reports do not clarify the effect of change in weather conditions and time of cotton sowing on CLCuD incidence, productivity of cotton cultivars. Management approaches (nutrition management, controlling vector, buffer cropping, seed treatment, sowing time etc) can help in reducing CLCuD incidence for first 40 days. This disease may vary for its severity among abiotic factors like temperature and plant age [11], weed eradication [12], development of resistant varieties along with agronomic and biotechnological methods [13].

Different varieties behave and respond differently in field conditions owing to the differences in structure, stature, leaf angle, leaf orientation, shape, leaf size etc beside crop duration. Cultivars vary for their response to biotic, abiotic stresses and climatic conditions because of differential genetic potential they possess [14]. The yield potential of any cultivar can only be expressed in a best possible way if it is given full chance for expression of its genes by sowing at a suitable time and at ideal space from each other. The rates of photosynthesis, transpiration and respiration also vary depending on varietal characters, environmental factors and management practices which ultimately determine the productivity of cotton. Different cultivars have different yield potential under varying environments $[15,16]$.

There is always a continuous need and challenge for scientists to acclimatize and standardize the agro-normals of newly evolved cultivars like those under present study. This study was undertaken because the literature available is not enough regarding suitable time when these new cotton cultivars should be sown in core cotton zone of Punjab Pakistan.

\section{Materials and Methods}

The field studies were conducted at latitude of $30^{\circ} 12 \mathrm{~N} 71^{\circ} 28 \mathrm{E}$ and altitude of $123 \mathrm{~m}$ for two consecutive years to evaluate the effect of sowing dates on seed cotton yield and CLCuD incidence of non $B t$ cotton cultivars. CIM-612 and CIM-573 were grown for both the years whereas CIM-591 was grown during year 1 and Cyto-124 during year 2, on five dates i.e., April 15, May 01, May 15, June 01 and June 15 having factorial 
arrangement under randomized complete block design (RCBD) replicated thrice. Bedfurrows $75 \mathrm{~cm}$ apart were prepared and weeds were controlled through preemergence application of pendimethalin at $825 \mathrm{~g}$ a.i. $\mathrm{ha}^{-1}$. After irrigating furrows, delinted cotton seeds were manually dibbled on respective sowing dates during both the growing seasons.

Phosphorus $\left(\mathrm{P}_{2} \mathrm{O}_{5}\right)$ in the form of triple super phosphate $(46 \%)$ was incorporated in the soil at the time of seedbed preparation at $50 \mathrm{~kg} \mathrm{ha}^{-}$ 1 . Nitrogen was applied at $150 \mathrm{~kg} \mathrm{ha}^{-1}$ in the form of urea $(46 \% \mathrm{~N})$ in three equal splits at bud formation, flowering and boll formation. Rest practices were maintained uniformly throughout the seasons. Observations on the incidence of $\mathrm{CLCuD}$ were recorded at fortnight interval from 30 days after planting and continued until 165 days. Total number of plants showing leaf curl virus disease symptoms (upward curling with thickened veins on underside of the leaf) were counted every time during observations. Plants with even a single leaf showing the symptoms of disease were counted as infected. The disease incidence was counted by using the following formula:

Disease incidence $(\%)=($ total plants - healthy plants / total plants) x 100

Data regarding yield parameters were taken at maturity. For recording parameters like boll weight, number of bolls per plant and plant height ten plants were selected at random from each plot. The seed cotton yield was recorded on per plot basis and converted to $\mathrm{kg} \mathrm{ha}^{-1}$.

The collected data were subjected to analysis of variance (ANOVA) using the MSTAT statistical computer package. The differences among the means of the treatments were compared by least significant difference (LSD) test at $\mathrm{P} \leq 0.5$ [17].

\section{Results and Discussion}

Year's effect was significant hence the data has been presented and discussed separately. Sowing dates and cultivars brought significant differences among each other for most of the yield parameters. Plant height was influenced significantly by different sowing dates (Table 1). The plant height reduced as the sowing was delayed. Crop sown on June 15 showed significantly shorter plants while the early sown crop April 15 produced the maximum plant height. The cultivar CIM-612 produced the taller plants during both the crop seasons. Shorter plants in delayed sowing have also been observed in other studies [5, 7, 18] which can be attributed to less time available for cotton plants to complete the phenological stages in sufficient time for normal growth.

Late seeding can bring reduction in boll weight upto $33.8 \%$ due to more prevalence of CLCuD [19]. Significantly higher boll weight was produced from the crop sown on June 15 among all non $B t$ cultivars. Among the sowing dates the boll weight ranged from 2.59 to $2.80 \mathrm{~g}$ during year 1 . However, for year 2 growing season boll weight ranged 2.44 to 2.55 g. Moreover, CIM-573 produced highest boll weight $(2.77 \mathrm{~g})$ and Cyto-124 $(2.52 \mathrm{~g})$ respectively during year 1 and year 2 (Table $2 \& 3$ ). Interactive effect of cultivars and sowing dates revealed significant variation with an overall increase in boll weight as the sowing was delayed in year 1 while boll weight could not vary significantly during growing season of year 2 (Table 3 ). It might be due to temperature fluctuation and variation in relative humidity (Fig. 1).

Higher bolls per plant in year 2 than the growing season of year 1 could be owing to differences in genetic potential of cultivars and variation in environmental conditions. However, CIM-591, during year 1 performed better than CIM-573, whereas in year 2 cultivars could not differ significantly due to changes in temperature and relative humidity in terms of number of bolls per plant (Table 2). The photosynthates started partitioning by differentiating and plants shifted to reproductive stage to complete their life cycle 
successfully. Significant differences during both the years could be due to environmental variation and subsequent insect pressure differences. The number of bolls per plant of three cultivars CIM-591, CIM-612 and CIM573 were 23, 20 and 22 during the year 1. While the cultivars CIM-612, Cyto-124 and CIM-573 produced number of bolls per plant 24,24 and 23 during year 2 , respectively. The number of bolls per plant of five sowing dates $15^{\text {th }}$ April, $1^{\text {st }}$ May, $15^{\text {th }}$ May, $1^{\text {st }}$ June and $15^{\text {th }}$ June were 27, 25, 22, 19 and 13 respectively during the year 1 and the subsequent figures for the year 2 were 31, 29, 24, 20 and 15 respectively.

The data on seed cotton yield of test cultivars affecting sowing dates (Table 2) indicated that on an overall average of cultivars, crop sown early on April 15 produced significantly higher seed cotton yield $(\mathrm{P}<$ $0.05) 2604$ and $2761 \mathrm{~kg} \mathrm{ha}^{-1}$ for year 1 and year 2 , respectively than other sowing dates (May 01, May 15, June 01 and June 15). While the late sowing date (June 15) produced the minimum seed cotton yield $1003 \mathrm{~kg} \mathrm{ha}^{-1}$ and $1197 \mathrm{~kg} \mathrm{ha}^{-1}$ during year 1 and year 2, respectively (Table 2). CIM-591 gave $2088 \mathrm{~kg} \mathrm{ha}^{-1}$ and Cyto-124 produced $2184 \mathrm{~kg} \mathrm{ha}^{-1}$ seed cotton yield during year 1 and year 2, respectively.

During year 1, CIM-591 performed better for seed cotton yield and bolls per plant when compared with other cultivars under test. Whereas during year 2, Cyto-124 exhibited a greater number of bolls per plant and seed cotton yield and was significantly higher than all the other cultivars under study. Higher seed cotton yield in year 2 than in year 1 could be attributed to more uniformity in rainfall pattern with resultant stable relative humidity prevailed during the $2^{\text {nd }}$ year. It was interesting to observe that CIM-612, reflected an overall marked reduction in $\mathrm{CLCuD}$ incidence. It means that this cultivar can also be planted between April 15 to May 01, without compromising much on seed cotton yield reflecting the wider time window potential of this non-Bt cultivar. However, it is also pertinent to state that further delay in sowing CIM-612 resulted in sharp increasing trend in $\mathrm{CLCuD}$ occurrence which in turn reduced seed cotton yield as well. Delaying the sowing of seed cotton drastically reduced yield and vice versa $[20,21]$. Better seed cotton yield in early sowing could be owing to timely availability of growth resources and less incidence of CLCuD (Table $4 \& 5$ ). At optimum time planting of cotton ensured less attack of sucking insects including whitefly which acts as a vector for CLCuD. Reduction in seed cotton yield is not only due to delayed sowing but also because of increased CLCuD infestation [21].

The incidence of disease was $15.53 \%$ at day 45 and reached to maximum (49.67\%) at 105 days after planting on crop seeded on $1^{\text {st }}$ June. The infection level was $59.14 \%$ at day 45 and increased $(73.17 \%)$ at day 90 after planting on $15^{\text {th }}$ June. Averaged across the cultivars, disease at low level $(0.1 \%)$ at day 45 after planting with the advancement of age, the incidence increased up to $47.90 \%$ at 150 days on that crop planted on $15^{\text {th }}$ April, year 1 (Table 4). The infection level was $2.50 \%$ at day 45 and attained its maximum (68.5\%) at 150 days after planting on crop seeded on $1^{\text {st }}$ May. However, incidence of CLCuD was $6.20 \%$ at day 45 and reached to its maximum level $71.4 \%$ at $135^{\text {th }}$ day of planting for crop sown on $15^{\text {th }}$ May. The incidence of disease started from $28.20 \%$ at day 45 and reached up to $78.7 \%$ at day 120 after planting for crop planted on $1^{\text {st }}$ June.

The expression and progression of CLCuD during the crop seasons of both years of study differed with sowing date. Averaged across the cultivars (no difference for CLCuD incidence) minimum incidence $(0.46 \%)$ was recorded at 45 days after planting and increased up to $1.39 \%$ at day 60 after planting when crop was sown on $15^{\text {th }}$ April, year 2 . The disease boosted up to $32.88 \%$ till 165 
days after sowing for crop seeded on $15^{\text {th }}$ April (Table 5). The infection level was 0.00 $\%$ at day 45 and increased (39.52\%) at day 150 after sowing for crop planted on $1^{\text {st }}$ May. However, CLCuD incidence was $4.72 \%$ at 45 days and reached to its maximum level $(52.12 \%)$ at 120 days after planting for crop seeded on $15^{\text {th }}$ May (Table 5).

At 45 days after sowing during both the growing seasons, early sowing i.e. $15^{\text {th }}$ April revealed less CLCuD incidence [22]. A gradual and significant rise in $\mathrm{CLCuD}$ incidence could be attributed to gradual increase in relative humidity as the growing season advanced. Whereas at 60 days after sowing (DAS), more CLCuD incidence in year 1 can be due to comparatively higher rainfall than the growing season of Year 2 (Fig. 1). At $105 \mathrm{DAS}$, the lower CLCuD infestation during year 2 as compared to same stage in year 1 could be owing to less rainfall received with no significant fluctuation in relative humidity. The incidence of $\mathrm{CLCu}$ disease increased as sowing was delayed. The crop planted on $15^{\text {th }}$ June start incidence of CLCuD $24.10 \%$ after 30 days which increased up to $89.30 \%$ at day 105 after planting for crop planted on $15^{\text {th }}$ June [22, 23]. The increased CLCuD incidence can also be attributed to increased whitefly damage at lateral stages. Hence more diseased plants of cotton cultivars were found [22].

Table 1. Interaction effects of Non-Bt cotton cultivars and sowing date on plant height

\begin{tabular}{|c|c|c|c|c|c|c|}
\hline \multirow{3}{*}{$\begin{array}{l}\text { Sowing Date } \\
\text { (SD) }\end{array}$} & \multicolumn{3}{|c|}{ Year 1} & \multicolumn{3}{|c|}{ Year 2} \\
\hline & \multicolumn{3}{|c|}{ Cultivars } & \multicolumn{3}{|c|}{ Cultivars } \\
\hline & CIM-612 & CIM-573 & CIM-591 & CIM-612 & Cyto-124 & CIM-573 \\
\hline April 15 & $125 \mathrm{a}$ & $109 \mathrm{~b}$ & $103 c$ & $120 \mathrm{a}$ & $110 \mathrm{~b}$ & $112 b$ \\
\hline May 01 & $116 \mathrm{~b}$ & $106 b c$ & $101 \mathrm{c}$ & $116 a b$ & $108 \mathrm{~b}$ & $102 \mathrm{c}$ \\
\hline May 15 & $112 b$ & $103 c$ & $101 \mathrm{c}$ & $108 \mathrm{~b}$ & $101 \mathrm{~cd}$ & $93 \mathrm{de}$ \\
\hline June 01 & $108 b$ & $89 d$ & 91d & $99 \mathrm{~cd}$ & $96 \mathrm{~d}$ & $89 \mathrm{e}$ \\
\hline June 15 & $101 \mathrm{c}$ & $76 \mathrm{e}$ & $75 \mathrm{e}$ & $84 \mathrm{e}$ & $85 \mathrm{e}$ & $78 f$ \\
\hline LSD & \multicolumn{3}{|c|}{$5 \% \quad$ SDxC $=4.82$} & \multicolumn{3}{|c|}{$\mathrm{DxC}=$} \\
\hline
\end{tabular}

Table 2. Boll weight, number of bolls per plant, plant height $(\mathrm{cm})$ and seed cotton yield $(\mathrm{kg}$ $h^{-1}$ ) as influenced by Non-Bt cotton cultivars and sowing date

\begin{tabular}{|c|c|c|c|c|c|c|c|c|}
\hline \multirow{2}{*}{ Treatments } & \multicolumn{3}{|c|}{ Boll weight (g) } & \multicolumn{2}{c|}{$\begin{array}{c}\text { Number of bolls } \\
\text { plant }\end{array}$} & \multicolumn{2}{c|}{$\begin{array}{c}\text { Plant height (cm) } \\
\text { Seed cotton yield } \\
\left(\mathbf{k g ~ h a}^{-1}\right)\end{array}$} \\
\hline Cultivars & Year 1 & Year 2 & Year 1 & Year 2 & Year 1 & Year 2 & Year 1 & Year 2 \\
\hline CIM-612 & $2.56 \mathrm{C}$ & $2.51 \mathrm{~A}$ & $20 \mathrm{~B}$ & 24 & $112 \mathrm{~A}$ & $105 \mathrm{~A}$ & $1825 \mathrm{~B}$ & $2135 \mathrm{~A}$ \\
\hline CIM-573 & $2.77 \mathrm{~A}$ & $2.46 \mathrm{~B}$ & $22 \mathrm{~A}$ & 23 & $97 \mathrm{~B}$ & $95 \mathrm{C}$ & $1994 \mathrm{~A}$ & $1942 \mathrm{~B}$ \\
\hline CIM-591 & $2.73 \mathrm{~B}$ & - & $23 \mathrm{~A}$ & - & $94 \mathrm{C}$ & - & $2088 \mathrm{~A}$ & - \\
\hline Cyto-124 & - & $2.52 \mathrm{~A}$ & - & 24 & - & $100 \mathrm{~B}$ & - & $2184 \mathrm{~A}$ \\
\hline LSD 5\% & $\mathbf{0 . 0 2}$ & $\mathbf{0 . 0 2}$ & $\mathbf{1 . 3 7}$ & $\mathbf{N S}$ & $\mathbf{2 . 1 6}$ & $\mathbf{2 . 2 7}$ & $\mathbf{1 1 2 . 6 8}$ & $\mathbf{1 1 1 . 1 8}$ \\
\hline \multicolumn{8}{|c|}{ Sowing Date } \\
\hline April 15 & $2.59 \mathrm{D}$ & $2.44 \mathrm{D}$ & $27 \mathrm{~A}$ & $31 \mathrm{~A}$ & $112 \mathrm{~A}$ & $114 \mathrm{~A}$ & $2604 \mathrm{~A}$ & $2761 \mathrm{~A}$ \\
\hline May 01 & $2.65 \mathrm{C}$ & $2.47 \mathrm{C}$ & $25 \mathrm{~A}$ & $29 \mathrm{~A}$ & $108 \mathrm{~B}$ & $109 \mathrm{~B}$ & $2431 \mathrm{~B}$ & $2562 \mathrm{~B}$ \\
\hline May 15 & $2.69 \mathrm{~B}$ & $2.50 \mathrm{~B}$ & $22 \mathrm{~B}$ & $24 \mathrm{~B}$ & $105 \mathrm{C}$ & $101 \mathrm{C}$ & $2161 \mathrm{C}$ & $2193 \mathrm{C}$ \\
\hline June 01 & $2.71 \mathrm{~B}$ & $2.53 \mathrm{~A}$ & $19 \mathrm{C}$ & $20 \mathrm{C}$ & $96 \mathrm{D}$ & $95 \mathrm{D}$ & $1646 \mathrm{D}$ & $1725 \mathrm{D}$ \\
\hline June 15 & $2.80 \mathrm{~A}$ & $2.55 \mathrm{~A}$ & $13 \mathrm{D}$ & $15 \mathrm{D}$ & $84 \mathrm{E}$ & $82 \mathrm{E}$ & $1003 \mathrm{E}$ & $1197 \mathrm{E}$ \\
\hline LSD 5\% & $\mathbf{0 . 0 2}$ & $\mathbf{0 . 0 2}$ & $\mathbf{2 . 0 7}$ & $\mathbf{2 . 0 4}$ & $\mathbf{2 . 7 4}$ & $\mathbf{3 . 1 0}$ & $\mathbf{1 0 1 . 0 0}$ & $\mathbf{9 3 . 9 9}$ \\
\hline
\end{tabular}

$\mathrm{NS}=$ Non- significant 
Table 3. Interaction effects of Non-Bt cotton cultivars and sowing date on boll weight (g)

\begin{tabular}{|c|c|c|c|c|c|c|}
\hline \multirow{2}{*}{$\begin{array}{c}\text { Sowing Date } \\
(\text { SD) }\end{array}$} & \multicolumn{3}{|c|}{ Year 1 } & \multicolumn{3}{c|}{ Year 2 } \\
\cline { 2 - 7 } & \multicolumn{3}{|c|}{ Cultivars (C) } & \multicolumn{3}{c|}{ Cultivars (C) } \\
\cline { 2 - 7 } & CIM-612 & CIM-573 & CIM-591 & CIM-612 & Cyto-124 & CIM-573 \\
\hline April 15 & $2.50 \mathrm{f}$ & $2.67 \mathrm{~d}$ & $2.60 \mathrm{e}$ & $2.45 \mathrm{~ns}$ & 2.46 & 2.43 \\
\hline May 01 & $2.56 \mathrm{e}$ & $2.75 \mathrm{c}$ & $2.83 \mathrm{bc}$ & 2.49 & 2.50 & 2.41 \\
\hline May 15 & $2.60 \mathrm{e}$ & $2.82 \mathrm{bc}$ & $2.99 \mathrm{a}$ & 2.52 & 2.51 & 2.46 \\
\hline June 01 & $2.57 \mathrm{e}$ & $2.84 \mathrm{~b}$ & $2.67 \mathrm{~d}$ & 2.55 & 2.56 & 2.49 \\
\hline June 15 & $2.59 \mathrm{e}$ & $2.79 \mathrm{c}$ & $2.57 \mathrm{e}$ & 2.56 & 2.56 & 2.53 \\
\hline LSD & \multicolumn{3}{|c|}{$\mathbf{5 \%}$ SDxC = 0.04 } & \multicolumn{3}{|c|}{$\mathbf{5 \%}$ SDxC = NS } \\
\hline
\end{tabular}

$\mathrm{NS}=$ no significant

Table 4. Cotton leaf curl disease incidence on different Non-Bt cultivars as influenced by sowing date during Year 1

\begin{tabular}{|c|c|c|c|c|c|c|c|c|c|c|c|}
\hline \multirow{2}{*}{$\begin{array}{c}\text { Sowing } \\
\text { dates }\end{array}$} & \multirow{2}{*}{ Cultivars } & \multicolumn{10}{|c|}{ CLCuD incidence percentage (DAS) } \\
\hline & & 30 & 45 & 60 & 75 & 90 & 105 & 120 & 135 & 150 & 165 \\
\hline \multirow{4}{*}{$\begin{array}{l}15^{\text {th }} \\
\text { April }\end{array}$} & CIM-591 & 0.0 & 0.4 & 2.9 & 13.5 & 32.8 & 43.3 & 53.3 & 66.8 & 80.3 & 88.0 \\
\hline & CIM-612 & 0.0 & 0.0 & 0.0 & 0.0 & 0.0 & 1.0 & 1.0 & 1.0 & 1.0 & 2.1 \\
\hline & CIM-573 & 0.0 & 0.0 & 4.1 & 11.7 & 31.0 & 37.2 & 51.3 & 57.8 & 62.3 & 66.3 \\
\hline & Average & $\mathbf{0 . 0}$ & 0.1 & 2.3 & 8.4 & 21.3 & 27.2 & 35.2 & 41.9 & 47.9 & 52.1 \\
\hline \multirow{4}{*}{$1^{\text {st }}$ May } & CIM-591 & 0.0 & 6.0 & 18.4 & 80.2 & 89.9 & 94.0 & 97.6 & 98.8 & 100.0 & \\
\hline & CIM-612 & 0.0 & 0.0 & 1.2 & 5.4 & 5.4 & 7.0 & 7.0 & 7.7 & 7.7 & \\
\hline & CIM-573 & 0.0 & 1.5 & 14.7 & 42.5 & 54.3 & 67.8 & 82.5 & 91.5 & 97.9 & \\
\hline & Average & 0.0 & 2.5 & 11.4 & 42.7 & 49.9 & 56.3 & 62.4 & 66.0 & 68.5 & \\
\hline \multirow{4}{*}{$\begin{array}{l}15^{\text {th }} \\
\text { May }\end{array}$} & CIM-591 & 0.6 & 8.0 & 55.0 & 87.3 & 96.3 & 97.5 & 100.0 & 100.0 & & \\
\hline & CIM-612 & 0.0 & 2.5 & 6.3 & 9.4 & 12.7 & 14.1 & 15.8 & 16.5 & & \\
\hline & CIM-573 & 0.0 & 8.0 & 44.1 & 73.0 & 85.9 & 89.9 & 96.9 & 97.8 & & \\
\hline & Average & 0.20 & 6.2 & 35.1 & 56.6 & 65.0 & 67.2 & 70.9 & 71.4 & & \\
\hline \multirow{4}{*}{$1^{\text {st }}$ June } & CIM-591 & 0.0 & 38.8 & 76.6 & 100.0 & 100.0 & 100.0 & 100.0 & & & \\
\hline & CIM-612 & 0.0 & 10.3 & 18.1 & 28.0 & 30.6 & 33.7 & 36.0 & & & \\
\hline & CIM-573 & 0.0 & 35.6 & 74.4 & 94.6 & 98.9 & 100.0 & 100.0 & & & \\
\hline & Average & 0.0 & 28.2 & 56.4 & 74.2 & 76.5 & 77.9 & 78.7 & & & \\
\hline \multirow{4}{*}{$\begin{array}{l}15^{\text {th }} \\
\text { June }\end{array}$} & CIM-591 & 22.6 & 81.2 & 100.0 & 100.0 & 100.0 & 100.0 & & & & \\
\hline & CIM-612 & 18.9 & 40.1 & 61.7 & 63.3 & 65.5 & 67.8 & & & & \\
\hline & CIM-573 & 30.8 & 59.3 & 100.0 & 100.0 & 100.0 & 100.0 & & & & \\
\hline & Average & 24.1 & 60.2 & 87.2 & 87.8 & 88.5 & 89.3 & & & & \\
\hline
\end{tabular}


Table 5. Cotton leaf curl disease incidence on different Non-Bt cultivars as influenced by sowing date during Year 2

\begin{tabular}{|c|c|c|c|c|c|c|c|c|c|c|c|}
\hline \multirow{2}{*}{$\begin{array}{c}\text { Sowing } \\
\text { dates }\end{array}$} & \multirow{2}{*}{ Cultivars } & \multicolumn{10}{|c|}{ CLCuD incidence percentage (DAS) } \\
\hline & & 30 & 45 & 60 & 75 & 90 & 105 & 120 & 135 & 150 & 165 \\
\hline \multirow{4}{*}{$\begin{array}{l}15^{\text {th }} \\
\text { April }\end{array}$} & CIM-573 & 0.0 & 1.39 & 3.72 & 16.2 & 48.1 & 63.85 & 80.56 & 87.75 & 91.03 & 91.03 \\
\hline & CIM-612 & 0.0 & 0.0 & 0.45 & 0.89 & 0.89 & 1.39 & 2.35 & 3.25 & 3.25 & 3.25 \\
\hline & Cyto-124 & 0.0 & 0.0 & 0.0 & 0.45 & 0.99 & 1.58 & 1.58 & 3.8 & 4.35 & 4.35 \\
\hline & Average & 0.0 & 0.46 & 1.39 & 5.85 & 16.66 & 22.27 & 28.16 & 31.6 & 32.88 & 32.88 \\
\hline \multirow{4}{*}{$1^{\text {st }}$ May } & CIM-573 & 0.0 & 0.0 & 4.64 & 29.74 & 72.48 & 87.26 & 92.02 & 98.53 & 98.53 & \\
\hline & CIM-612 & 0.0 & 0.0 & 1.96 & 2.98 & 5.34 & 8.29 & 8.29 & 8.29 & 8.29 & \\
\hline & Cyto-124 & 0.0 & 0.0 & 0.0 & 1.43 & 4.17 & 6.71 & 10.48 & 11.74 & 11.74 & \\
\hline & Average & 0.0 & 0.0 & 2.2 & 11.38 & 27.33 & 34.09 & 36.93 & 39.52 & 39.52 & \\
\hline \multirow{4}{*}{$\begin{array}{l}15^{\text {th }} \\
\text { May }\end{array}$} & CIM-573 & 4.57 & 13.19 & 51.96 & 90.47 & 98.66 & 99.38 & 100 & 100 & & \\
\hline & CIM-612 & 0.0 & 0.98 & 5.27 & 14.48 & 26.8 & 28.59 & 30.46 & 30.46 & & \\
\hline & Cyto-124 & 0.0 & 0.0 & 4.47 & 14.09 & 23.72 & 25.91 & 25.91 & 25.91 & & \\
\hline & Average & 1.52 & 4.72 & 20.57 & 39.68 & 49.73 & 51.29 & 52.12 & 52.12 & & \\
\hline \multirow{4}{*}{$1^{\text {st }}$ June } & CIM-573 & 2.64 & 42.0 & 71.63 & 90.15 & 94.19 & 97.1 & 97.1 & & & \\
\hline & CIM-612 & 0.0 & 4.6 & 13.64 & 27.13 & 30.80 & 36.1 & 36.1 & & & \\
\hline & Cyto-124 & 0.0 & 0.0 & 5.16 & 11.37 & 12.05 & 15.82 & 15.82 & & & \\
\hline & Average & 0.88 & $\mathbf{1 5 . 5 3}$ & 30.14 & 42.88 & 45.68 & 49.67 & 49.67 & & & \\
\hline \multirow{4}{*}{$\begin{array}{l}15^{\text {th }} \\
\text { June }\end{array}$} & CIM-573 & 9.12 & 87.42 & 98.72 & 98.72 & 100 & 100 & & & & \\
\hline & CIM-612 & 14.43 & 79.35 & 100 & 100 & 100 & 100 & & & & \\
\hline & Cyto-124 & 0.7 & 10.64 & 16.5 & 17.89 & 19.5 & 19.5 & & & & \\
\hline & Average & 8.08 & 59.14 & 71.74 & 72.20 & 73.17 & 73.17 & & & & \\
\hline
\end{tabular}

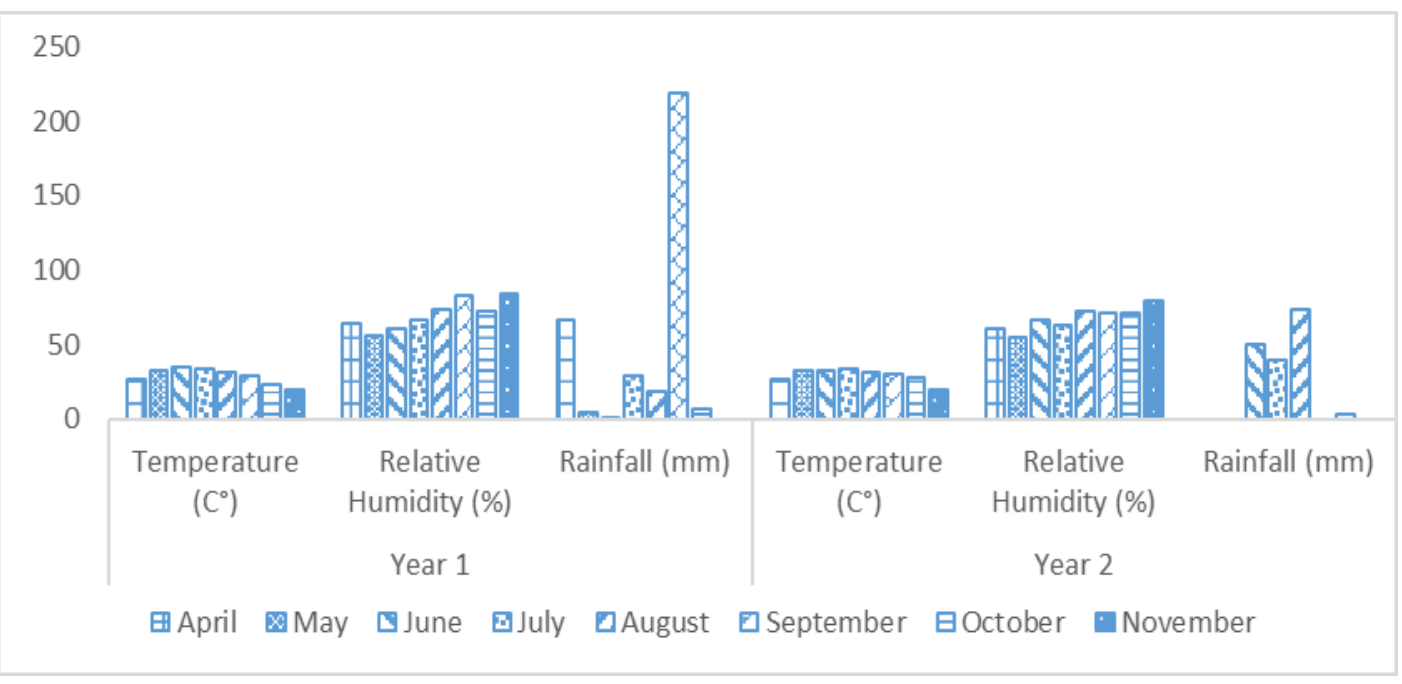

Figure 1. Metrological data of two consecutive cotton growing years

\section{Conclusion}

CLCuD being a complex disease is affected by many factors including sowing date. All the non $B t$ varieties sown earlier showed higher seed cotton yield and less incidence of CLCuD probably as a result of provision of improved agri-environmental resources and more time availability. Hence farmers who want to grow non- $B t$ cotton varieties may not delay the cotton sowing. However, it can be suggested that under the prevailing agroenvironmental normals; non- $B t$ cotton 
variety CIM-612 sown on April 15 in core zone of Punjab (Pakistan) may aid in getting overall improved seed cotton yield with least chances of CLCuD incidence. Planting of suggested non- $B t$ variety is also very important under the backdrop of prevailing constraints and challenges being faced in the productivity of $B t$ cotton varieties.

\section{Authors' contributions}

Conceived the idea and designed the experiment: D Muhammad, Performed the experiment: M Ahmad \& M Tariq, Analyzed the data: K Mubeen \& MW Yonas, Contributed materials/ analysis/ tools: $\mathrm{MN}$ Afzal, Wrote the paper: M Shehzad \& M Aziz.

\section{Acknowledgement}

The authors acknowledge the support by Central Cotton Research Institute, Multan.

\section{References}

1. Nadeem MA, Idress M, Tanveer A, Ayub M \& Mubeen K (2013). Effect of different weed control practices and sowing methods on weeds and yield of cotton. Pak J Bot 45(4): 1321-1328.

2. GOP (Government of Pakistan) (2018). Pakistan Economic Survey, 2017-18. Government of Pakistan, Finance Division, Economic Adviser's Wing, Islamabad, Pakistan. pp. 14-19.

3. Soomro AR, Channa MH, Channa AA, Kalwar GH, Dayo GN \& Memon AH (2000). The effect of different sowing dates on the yield of newly developed strain under climatic conditions of Ghotki, Sindh. The Pak Cott 3(11): 19011903.

4. Ali M, Mohy-ud-Din G, Ali MA, Bashir $S \&$ Ali L (2004). Cotton yield as affected by different sowing dates. Inter $J$ of Agric and Biol 6(4): 644-646.

5. Ali H, Muhammad D, Afzal MN \& Abid SA (2005). Seed cotton yield of different cultivars as affected by sowing time under agro climatic conditions of
Southern Punjab. The Indus Cott 2(3): 186-189.

6. Nazir MS, Khan AA, Khan RSA, Masooma H, Cheema N \& Shakeel A (2018). Sustainable cotton production under CLCuD threat. Pak J of Agric Sci 55(2): 279-285.

7. Akhtar MM, Cheema MS, Shahid MJ \& Shahid MI (2002). Response of cotton genotypes to time of sowing. Asian $J$ of Plant Sci 1(5): 538-539.

8. Muhammad D, Anwar M \& Afzal MN (2002). Evaluation of different cotton varieties at different sowing dates. Basic Appl. Ecol 19: 7-13. Retrieved from https://scholar.google.com/scholar?hl=e n\&as_sdt $=0 \% 2 \mathrm{C} 5 \& \mathrm{q}=+$ Evaluation + of + different+cotton+varieties+at+different+ sowing+dates.+Basic + Appl.+Ecol+19\% $3 \mathrm{~A}+7-13 . \& \mathrm{btnG}=$

9. Bauer, PJ, Frederic JJr, Bradow JM, Sadler EJr \& Evans DE (2000). Canopy photosynthesis and fiber properties of normal and late planted cotton. J of Agron 92(3): 518-523.

10. Pettigrew WT (2002). Improved yield potential with an early planting cotton production system. Agron J 94(5): 9771003.

11. Farooq A, Farooq J, Mahmood A, Shakeel A, Rehman KA, Batool A, Riaz M, Shahid MTH \& Mehboob S (2011). An overview of cotton leaf curl virus disease (CLCuD) a serious threat to cotton productivity. Aust J of Crop Sci 5(13): 1823-1831.

12. Monga D, Narula AM \& Raj S (2001). Management of cotton leaf curl virus- A dreaded disease in north India, pp. 112115. Paper published in Book of papers of National seminar on Sustainable cotton production to meet the future requirement of industry. Organized by Kapas Vikas Nideshalya, Directorate of cotton development, Government of India. 
13. Farooq J, Farooq A, Riaz M, Shahid MR, Saeed F, Iqbal MS, Hussain T, Batool A \& Mahmood A (2014). Cotton leaf curl virus disease a principle cause of decline in cotton productivity in Pakistan (a mini review). Cana J of Plant Prot 2(1): 9-16.

14. Iqbal J, Wajid SA, Ahmad A \& Arshad M (2012). Comparative studies on seed cotton yield in relation to nitrogen rates and sowing dates under diverse agro environment of Punjab. Pak $J$ of $S c i$ 64(1): 59-63.

15. Bange MP \& Milory SP (2000). Timing of crop maturity in cotton. Impact of dry matter production and partitioning. Field Crops Res 68(2): 143-155.

16. Wajid A, Ahmad A, Khaliq T, Aslam S, Hussain A, Naseem W, Usman M \& Ahmad S (2010). Quantification of growth, yield and radiation use efficiency of promising cotton cultivars at varying nitrogen level. Pak J of Bot 42(3): 17031711.

17. Steel RGD, Torrie JH \& Dickey DA (1997). Principles and practices of statistics, A biometric Approach. $3^{\text {rd }}$ Ed. Mc Graw Hill, Int. Book Co. Inc. Singapore.

18. Ahmed Z (1999). Prospects and bottlenecks of cotton crop in Pakistan. The Pak Cott Grower 3: 6-7. https://scholar.google.com/scholar?clust er=7100393846974588068\&hl=en\&as_s $\mathrm{dt}=2005 \&$ sciodt $=0,5$

19. Ali H, Afzal MN \& Muhammad D (2009). Effect of sowing dates and plant spacing on growth and dry matter partitioning in cotton (Gossypium hirsutum L.) Pak J of Bot 41(5): 21452155.

20. James JM, Wright DL, Wiatrak PJ \& Vargas MA (2004). Effect of row width and nitrogen on cotton morphology and canopy microclimate. Crop Sci 44(3): 707-710.

21. Iqbal M \& Khan MA (2010). Management of Cotton leaf Curl Virus by planting time and plant spacing. Advances in Agriculture \& BotanicsInter J of the Bioflux Soc 2(1): 25-34.

22. Tahir M, Mahmood T, Mahmood HT \& Hussain S (2004). Effect of sowing dates on incidence of cotton leaf curl virus on different cultivars of cotton. Plant Pathol J 3(2): 61-64.

23. Mahmood T, Tahir M, Mahmood HT, Hussain S \& Muhammad D 2014. Effect of plant age on cotton leaf curl disease (CLCuD) in relation to environmental conditions. Pak J of Sci and Indus Res Serial B: Biol Sci 57(1): 18-24. 